\title{
Solusi Konflik Sosial dalam Perspektif al-Qur'an
}

\author{
Sukring \\ Fakultas Hukum Universitas Halu Oleo Kendari \\ Email: sukring_69@yahoo.co
}

\begin{abstract}
Abstrak
Social life, if scrutiny is the main component of interaction between the members. In connection with the interaction among members was found various types. The types of social interaction in general include: cooperative (co-operation), competition (competition) and conflict (contention). In everyday social life seems besides characterized by cooperation, constantly marred by various forms of competition and conflict. Even in social life has never been found all citizens of all time cooperative. The teachings of Islam (al-Qur'an) has been tested in the history of the Prophet in unifying the Aus and Kasraj, warring for hundreds of years. Conflict and human, these two are inseparable. Therefore, conflict is a part of a necessity in life (min lawazim al-hayat) human. It is not excessive if some experts say that human history is a history of conflict. But that does not mean that the conflict left without any attempt to manage and mute. So this paper attempts to explore the spirit to manage and reduce conflicts and solutions in the perspective of the Koran.
\end{abstract}

Kehidupan sosial itu, kalau dicermati komponen utamanya adalah interkasi antara para anggota. Sehubungan dengan interaksi antaranggota itu ditemukan berbagai tipe. Tipe-tipe interaksi sosial secara umum meliputi: cooperative (kerjasama), competition (persaingan) dan conflict (pertikaian). Dalam kehidupan sosial sehari-hari tampaknya selain diwarnai oleh kerjasama, senantiasa juga diwarnai oleh berbagai bentuk persaingan dan konflik. Bahkan dalam kehidupan sosial tidak pernah ditemukan seluruh warganya sepanjang masa kooperatif. Ajaran agama Islam (alQur'an) telah teruji dalam sejarah Nabi SAW dalam mempersatukan kaum Aus dan Kasraj, yang bertikai ratusan tahun lamanya. Konflik dan manusia, keduanya tidak dapat dipisahkan. Oleh karena konflik merupakan bagian dari keniscayaan dalam kehidupan (minlawazimal-hayat) manusia. Maka tidak berlebihan jika sebagian pakar mengatakan bahwa sejarah manusia adalah sejarah konflik. Namun bukan berarti bahwa konflik dibiarkan begitu saja tanpa adanya upaya untuk mengelola dan meredamnya. Maka tulisan ini mencoba menggali spirit dalam mengelola dan meredam konflik dan solusi dalamperspektif al-Quran

Keywords: Solution, social conflict, perspective, al-Qur'an 
Millatī, Journal of Islamic Studies and Humanities, Vol. 1, No. 1, Juni 2016: 103-122

\section{Pendahuluan}

Dalampemikiranawam, konflik mestilah suatu perbuatan yang negatif. Menurut Soerjono Soekanto ${ }^{1}$ konflik merupakan suatu proses sosial di mana orang perorangan atau kelompok manusia berusaha untuk memenuhi tujuannya dengan jalan menentang pihak lawan yang disertai ancaman atau kekerasan. Sementara, Coser $^{2}$ berpendapat bahwa konflik dapat merupakan proses yang bersifat instrumental dalam pembentukan, penyatuan dan pemeliharaan struktur sosial. Konflik dapat menempatkan dan menjaga garis batas antara dua atau lebih kelompok. Konflik dengan kelompok lain dapat memperkuat kembali identitas kelompok dan melindunginya agar tidak lebur ke dalam dunia sosial sekelilingnya. ${ }^{3}$

Pendapat Coserini nampaknya lebih menilai konflik dari sudut pandang yang positif, artinya ada yang dihasilkan dalam suatu konflik, hasil mana justeru menguntungkan pihak-pihak yang terlibat konflik. Misalnya, perang yang terjadi bertahun-tahun di Timur Tengah telah memperkuat identitas kelompok Negara Arab dan Israel. ${ }^{4}$

Suatu perubahan dalam masyarakat bias terjadi dalam berbagai aspek kehidupan, baik pada nilai-nilai sosial, pola-pola perilaku organisasi, susunan kelembagaan kemasyarakatan, lapisan-lapisan dalam masyarakat, kekuasaan dan wewenang, maupun interaksi social dan sebagainya. Perubahan-perubahan yang terjadi pada masyarakat dunia global saat ini merupakan gejala yang normal. Pengaruh perubahan itu bisa meluas di berbagai Negara di belahanduniaini. ${ }^{5}$

Setiap masyarakat pasti mengalami perubahan-perubahan baik perubahan dalam arti luas maupun perubahan dalam arti sempit, perubahan secara cepat (revolusi) atau perubahan secara lambat (evolusi).Padaperinsipnya, perubahan dalam masyaraka merupakan proses yang terus-menerus. Dalam masyarakat maju maupun berkembang, perubahansosial, kebudayaan, ekonomi, dan lain-lain.

Lantas bagaimana kita bersikap terhadap perubahandan kelebihan di antara kita? Islam sangat memperhatikan akhlak atau perilaku yang baik ter-

\footnotetext{
${ }^{1}$ SoerjonoSoekanto,Sosiologi Suatu Pengantar, (Jakarta: Rajawali Pers), 2007,h..335

${ }^{2}$ Lewis Coser, The Function of Social Conflict. (New York: Free Press, 1956), h.. 151-210.

${ }^{3}$ Ibid.,

${ }^{4}$ Ibid.,

${ }^{5}$ Riyadi Soeprapto, InteraksionismeSimbolik, PerspektifSosiologi Modern, (Jakarta: PT. PustakaPelajardanAveroes Press Malang, 2002), h. 5.
} 
hadap orang lain.Umat Islam diperintahkan untuk menghormati orang yang mempunyai keutamaan, apakah itu kekuasaan, ilmu, kekayaan, dan kehormatan, bila semua itu dalam konteks ketaqwaan.Penguasa yang adil sangat dimuliakan dalam Islam. Kita harus taat padanya.Orang yang berilmu ('alim) sangat dimuliakan dalam Islam. Kita harus menghormatinya.Orang kaya yang dermawan, mempunyai kedudukan yang mulia dalam Islam. Kita harus menghormatinya.Orang yang berjasa kepada masyarakat, mempunyai kedudukan yang mulia dalam Islam. Kita harus menghormatinya.

Itu artinya, adanya stratifikasi sosial dalam masyarakat merupakan hal yang wajar. Karena anggota masyarakat mempunyai perbedaan kelebihan. Penghormatan kepada orang yang mempunyai kelebihan, dalam konteks ketaqwaan, juga diperintahkan dalam Islam.Namun, ada tapinya. Bila strata itu dalam konteks kasta, seperti kasta di India, yang menetapkan kasta tertentu lebih tinggi kedudukannya dan ada beberapa aturan yang membeda-bedakan antar kasta, hal tersebut tidak sesuai dengan ajaran Islam.

\section{Pengertian Konflik}

Robbins sebagaimana dikutip Sopiah, ${ }^{6}$ mendefinisikan konflik sebagai suatu proses yang dimulai bila satu pihak merasakan bahwa pihak lain telah mempengaruhi secara negative atau akan segera mempengaruhi secara negatif pihak lain. Dalam Kamus Besar Bahasa Indonesia; yaitu percekcokan, perselisihan, pertentangan antara dua kekuatan. Konflik sosial adalah pertentangan antaranggota masyarakat yang bersifat menyeluruh. ${ }^{7}$

Dari kedua definisi ini dapat disimpulkan bahwa konflik itu adalah proses yang dinamis dan keberadaannya lebih banyak menyangkut persepsi dari orang atau pihak yang mengalami dan merasakannya. Jadi jika suatu keadaan tidak dirasakan sebagai konflik maka pada dasarnya konflik itu tidak ada. Begitu juga sebaliknya.

Secara teoritis, konflik merupakan bagian dari dinamika sosial yang lumrah terjadi dan merupakan salah satu bentuk dari proses interaksi dalam tatanan pergaulan masyarakat. ${ }^{8}$ Konflik juga dapat berperan sebagai pemicu

\footnotetext{
${ }^{6}$ Sopiah, Perilaku Organisasi, (Yogyakarta : Penerbit Andi, 2000), h.. 24.

${ }^{7}$ Departemen Pendidikan Nasional, Kamus Besar Bahasa Indonesia, Ed.III, (Balai Pustaka;2000), h. . 587.

${ }^{8}$ Doyle Paul johnson, Sociological Theory Classical fonders and Contemporary Perspectives, jili I, terj. Robert. M.Z. Lawang, (Jakarta: Gramedia, 1988), h. 158.
} 
proses menuju terciptanya suatu keseimbangan sosial, melalui proses tawarmenawar, konflik dapat membantu terciptanya tatanan baru dalam interaksi sosial sesuai dengan kesepakatan bersama. ${ }^{9}$ Bahwa konflik merupakan sesuatu yang dapat dihindari, karena konflik melekat erat dalam jalinan dalam kehidupan masyarakat.

\section{Jenis dan Penyebab Konflik}

Jenis Konflik dibedakan dalam beberapa perspektif, antara lain :

$\checkmark$ Konflik intra individu. Konflik ini dialami oleh individu dengan dirinya sendiri karena adanya tekanan peran dan ekspektasi di luar berbeda dengan keinginan atau harapannya.

$\checkmark$ Konflik antar individu. Konflik yang terjadi antar individu yang berada dalam suatu kelompok atau antar individu pada kelompok yang berbeda.

$\checkmark$ Konflik antar kelompok. Konflik yang bersifat kolektif antara satu kelompok dengan kelompok lain.

$\checkmark$ Konflik organisasi. Konflik yang terjadi antara unit organisasi yang bersifat struktural maupun fungsional. Controh konflik antara bagian pemasaran dengan bagian produksi.

Ditinjau dari fungsinya, ada dua jenis konflik, yaitu :

$\checkmark$ Konflik konstruktif, adalah konflik yang memiliki nilai positif bagi pengembangan organisasi

$\checkmark$ Konflik destruktif, adalah konflik yang berdampak negatif bagi pengembangan organisasi.

Ditinjau dari segi instansionalnya, konflik dibagi menjadi tiga jenis, yaitu :

$\checkmark$ Konflik kebutuhan individu dengan peran yang dimainkan dalam organisasi. Tidak jarang kebutuhan dan keinginan karyawan bertentangan atau tidak sejalan dengan kebutuhan dan kepentingan organisasi. Hal ini bisa memunculkan konflik

$\checkmark$ Konflik peranan dengan peranan. Setiap karyawan organisasi memiliki peran yang berbeda-beda dan ada kalanya perbedaan peran tiap individu tersebut memunculkan konflik karena setiap individu berusaha untuk memainkan peran tersebut dengan sebaik-baiknya.

${ }^{9}$ K.J. Veeger, Realitas Sosial, Refleksi Filsafat Sosial Atas Hubungan Individu Masyarakat Dalam Cakrawala Sejarah sosiologi, (Jakarta: PT. Gramedia Pustaka Utama, 1985), h. 78. 
$\checkmark$ Konflik individu dengan individu lainnya. Konflik seringkali muncul jika seorang individu berinteraksi dengan individu lain, disebabkan oleh latar belakang, pola pikir, pola tindak, kepribadian, minat, persepsi, atau sejumlah karakteristik yang berbeda antara yang satu dengan yang lain.

Ditinjau dari segi materi/masalah yang menjadi sumber konflik, konflik dapat dibedakan menjadi :

$\checkmark$ Konflik tujuan. Adanya perbedaan tujuan antar individu, kelompok, atau organisasi bisa memunculkan konflik.

$\checkmark$ Konflik peranan. Setiap manusia memiliki pearn lebih dari satu. Peran yang dimainkan, yang jumlahnya banyak tersebut, seringkali memunculkan konflik.

$\checkmark$ Konflik nilai. Nilai yang dianut seseorang seringkali tidak sejalan dengan sistem nilai yang dianut orgnisasi atau kelompok. Hal ini berpotensi untuk memunculkan konflik.

$\checkmark$ Konflik kebijakan. Konflik ini muncul karena seorang individu atau kelompok tidak sependapat dengan kebijakan yang ditetapkan organisasi

Mastenbroek dalam sopiah; ${ }^{10}$ membagi konflik menjadi empat, yaitu :

$\checkmark$ Instrumental conflicts

Konflik terjadi karena adanya ketidaksepahaman antarkomponen dalam organisai dan proses pengoperasiannya.

$\checkmark$ Socio-emotional conflicts

Konflik ini berkaitan dengan identitas, kandungan emosi, citra diri, prasangka, kepercayaan, keterikatan, identifikasi terhadap kelompok, lembaga dan lambang-lambang tertentu, sistem nilai dan reaksi individu dengan yang lainnya.

$\checkmark$ Negative conflicts

Konflik negosiasi adalah ketegangan-ketegangan yang dirasakan pada waktu proses negosiasi terjadi, baik antara individu dengan individu atau kelompok dengan kelompok.

$\checkmark$ Power and dependency conflicts

Konflik kekuasaan dan ketergantungan berkaitan dengan persaingan dalam organisasi, misalnya pengamanan dan penguatan kedudukan yang strategis.

\footnotetext{
${ }^{10}$ Sopiah, PerilakuOrganisasi,.
} 
Penyebab konflik ada bermacam-macam. Beberapa sebab penting adalah sebagai berikut:

Saling bergantung. Saling bergantung dalam pekerjaan terjadi jika dua kelompok organisasi atau lebih saling membutuhkan satu sama lain guna menyelesaikan tugas.

Perbedaan tujuan. Perbedaan tujuan yang ada diantara satu bagian dengan bagian yang lain, seperti unit produksi yang bertujuan semaksimal mungkin biaya produksi dan mengusahakan sedikit mungkin kerusakan produk, sementara bagian penelitian dan pengembangan berurusan dengan pengembangan ide-ide baru untuk mengubah dan mengembangkan produk yang berhasil secara komersial. Hal ini dapat menjadi potensi konflik.

Perbedaan persepsi. Dalam menghadapi suatu masalah, jika terjadi perbedaan persepsi maka hal itu dapat menyebabkan munculnya konflik.

\section{Proses Konflik}

Menurut pondi sebagaimana dikutip Sopia. ${ }^{11}$

$\checkmark$ Tahap I, Latent Conflict, konflik laten, yaitu tahap munculnya faktor-faktor yang menjadi penyebab konflik dalam organisasi. Bentuk-bentuk dasar dari situasi ini adalah persaingan untuk memperebutkan sumberdaya yang terbatas, konflik peran, persaingan perebutan posisi dalam organisasi, dll

$\checkmark$ Tahap II, Perceived Conflict, konflik yang dipersepsikan. Pada tahap ini salah satu pihak memandang pihak lain sebagai penghambat atau mengancam pencapaian tujuananya.

$\checkmark$ Tahap III, Felt Conflict, konflik yang dirasakan. Pada tahap ini konflik tidak sekedar dipandang ada akan tetapi sudah benar-benar dirasakan

$\checkmark$ Tahap IV, Manifest Conflict, konflik yang dimanifestasikan. Pada tahap ini perilaku tertentu sebagai indikator konflik sudah mulai ditunjukkan, seperti adanya sabotase, agresi terbuka, konfrontasi, rendahnya kinerja, dll.

$\checkmark$ Tahap V, Conflict Resolution, resolusi konflik. Pada tahap ini konflik yang terjadi diselesaikan dengan berbagai macam cara dan pendekatan.

$\checkmark$ Tahap VI, Conflict Aftermath. Jika konflik sudah benar-benar diselesaikan maka hal itu akan meningkatkan hubungan para anggota organisasi. Hanya

\footnotetext{
${ }^{11}$ Ibid., h. 67.
} 
saja jika penyelesaiannya tidak tepat maka akan dapat menimbulkan konflik baru.

\section{Pandangan Islam tentang Konflik Sosial}

Menurut para ilmuwan sosial, kehidupan manusia yang terbentang sepanjang sejarah selalu dibayang-bayangi oleh apa yang disebut agama. Bahkan, dalam kehidupan sekarang pun dengan kemajuan teknologi supra modern manusia tak luput dari agama. Agama lahir pada babak sejarah pramodern, sebelum masyarakat dan dunia diwaranai perkembangan pesat ilmu dan teknik. Berger ${ }^{12}$ melukiskan agama sebagai kebutuhan dasar manusia, karena agama merupakan sarana untuk membela diri terhadap segala kekacauan yang mengancam hidup manusia. Hampir semua masyarakat manusia mempunyai agama. Agama dapat dipandang sebagai kepercayaan dan pola prilaku yang diusahakan oleh suatu masyarakat untuk menangani masalan penting yang tidak dapat dipecahkan oleh teknologi dan tenik organisasi yang diketahuinya. Untuk mengatasi keterbatasan itu, orang berpaling kepada menipulasi kekuatan supranatural.

Nottingham seorang sosiolog berpendapat bahwa agama bukan suatu yang dapat di pahami melalui definisi, melainkan melalui deskripsi, ${ }^{13}$ menurutnya agama adalah gejala yang begitu sering "terdapat di mana-mana", dan agama berkaitan dengan usaha-usaha manusia untuk mengukur dalam makna dari keberadaban diri sendiri dan keberadaban alam semesta. Selain itu membangkitkan kebahagiaan batin yang paling sempurna, dan perasaan takut dan ngeri. Meskipun perhatian tertuju kepada adanya suatu dunia yang tak dapat dilihat (akhirat), namun agama melibatkan dirinya dalam masalah-masalah kehidupan sehari-hari di dunia.

Secara umum, agama adalah seperangkat aturan atau peraturan yang mengatur hubungan manusia dengan Tuhan. Hubungan manusia dengan sesamanya dan manusia dengan alam lingkungannya,yang kesemuanya itu didasarkan pada keyakinan terhadap adanya Tuhan. Pada sisi ini agama dilihat sebagai teks dan doktrin, sehingga keterlibatan manusia sebagai pemeluk atau penganut agama tidak nampak tercakup di dalamnya. Karena itu, masalah-

\footnotetext{
${ }^{12}$ Peter L. Berger, The Sacred Canapy, terj. Hartono, (LP3ES, Jakarta, 1991), hal. 73.

${ }^{13}$ Nottingham, K. Elizabeth, Agama dan Masyarakat, Suatu Pengantar Sosiologi Agama, terj. Abd. Muis Narahong, (Rajawali, Jakarta, 1990), h.. 34-35.
} 
masalah yang berkenaan dengan kehidupan keagamaan baik individual maupun kelompok, pengetahuan dan keyakinan yang lainnya yang dipunyai manusia, peranan keyakinan keagamaan terhadap kehidupan duniawi dan sebaliknya, kelestarian serta perubahan-perubahan keyakinan keagamaan yang dimiliki manusia, tidak tercakup dalam definisi tersebut. Sedangkan secara khusus, agama adalah suatu sistem keyakinan yang dianut dan tindakan-tindakan yang diwujudkan oleh suatu masyarakat dalam menginterprestasikan dan memberi respon terhadap apa yang dirasakan dan diyakini sebagai yang ghaib dan suci. Sebagai suatu sistem keyakinan, agama berbeda dari sistem-sistem keyakinan atau isme-isme lainnya, karena landasan keyakinan keagamaan adalah konsep suci yang dibedakan dari, atau dipertentangkan dengan yang duniawi (profane), dan pada yang ghaib atau supranatural yang menjadi lawan dari hukumhukum aimiah. ${ }^{14}$

Dari segi sosiologis, agama tidak hanya dimaksudkan sebagai perangkat ajaran yang berlaku mutlak yang datang dari Tuhan, tetapi juga merupakan bagian yang mendalam dari kebudayaan. Sebagai mana yang diungkapkan oleh Greet, agama merupakan sistem simbol yang bertindak untuk memantabkan perasaan-perasaan dan motivasi-motivasi secara kuat dan bertahan lama dalam diri manusia, dengan cara merumuskan konsepsi-konsepsi mengenai hukumhukum yang berlaku umum dan menyelimuti kosepsi-konsepsi ini dengan suasana kepastian faktual sehingga suasana hati dan motivasi itu terasa sungguhsungguh realistis.16 Dalam kehidupan masyarakat, agama mempunyai peranan sangat penting, karena agama berisikan ajaran-ajaran tentang kebenaran yang tertinggi dan mutlak tantang keberadaan manusia dan petunjuk-petunjuk untuk hidup bahagia. Oleh karena itu, ajaran agama harus duaktualisasikan dalam kehidupan para pemeluknya.

Pada saat agama teraktuaslisas dalam masyarakat, maka agama menjadi realitas sosial, yang beritegrasi dengaan sistem nilai sosial dan budaya masyarakat. Secara sosiologis, agama dalam realitas kehidupan pemeluknya akan bersentuhan dengan pemenuhan kebutuhan hidup manusia, baik bersifat fisik-biologis, sosial, ekonomi dan politik, maupun kebutuhan spiritual, moral dan hal-hal lain yang bersifat eksistensial. Dengan demikian keberagaman saling kait mengkait dengan dimensi normatif, faham dan keyakinan, serta dimensi dan

${ }^{14}$ Abu Sofyan, Pluralisme Keberagaman di Pemukiman Baru, Studi Tentang Konflik dan Integrasi Antara Warga Nahdlotul 'Ulama dengan Muhammadiyah di Perumahan Taman Jenggala Sidoarjo, (Umm, Malang, 2001), h. 12-13 
dinamika kehidupan aktual, baik dalam level individual maupun kolektiforganisasi keagamaan itu sendiri merupakan suatu lembaga yang tidak begitu jauh terpisah dan merupakan salah satu aspek dari keseluruhan aktifitas yang lain, baik yang bersifat ekonomis, politik, kekeluargaan maupun rekreatif. ${ }^{15}$

Agama dan masyarakat merupakan hubungan yang dialektif, keduanya saling mempengaruhi, saling mendorong dan saling menekan menuju perkembangan suatu masyarakat secara dinamis dan mewujudkan pasang surut peran agama dalam masyarakat, sehingga hubungan agama dengan kuhidupan masyarakat bisa mengarah pada traspormasi nilai dan struktur dalam kehidupan masyarakat sehingga terjadi perubahan. ${ }^{16}$

Pada saat dimensi normatif faham dan keyakinan agama diaktualisasikan dalam kehidupan kemasyarakatan, selain melahirkan rasa kedamaian dan saling menghargai, sering pula melahirkan konflik berkepanjangan, yang dapat mengganggu bahkan merusak kedamaian hidup masyarakat. Dengan kata lain, ketika agama berada pada tingkat masyarakat, ia melahirkan fungsi integrasi dan fungsi konflik sosial.

Realitas sejarah menunjukkan bahwa, Agama Islam pada zaman Nabi Muhammad SAW. Tidak mengalami perbedaan faham yang membawa kepada perpecahan pemeluknya, karena semua persoalan yang ada dapat diselesaikan oleh Nabi sendiri, sehingga terlihat adanya hidup rukun antara dua kelompok sahabat Nabi yaitu : Muhajirin dan Anshor. Setelah Nabi Muhammad wafat dan menyebar keberbagai daerah yang luas, maka agama islam memasuki zaman yang situasi, kultur dan sosialnya jauh berbeda dengan situasi asalnya, maka timbullah perpecahan pemeluknya dikarenakan pemahaman yang berbeda, sehingga dikenal dalam sejarah dinamakan golongan Khawarji, Murji'ah, Mu'tazilah dan lain-lain. Di Indonesia juga dikenal adanya golongan Muhammadiyah, Al-Irsyat, Nahdlatul Ulama', Persis dan lain-lainnya. Masing-masing golongan saling mencari dalil untuk membenarkan golongan dirinya dan menyalahkan golongan lain. Hal ini akan menimbulkan konflik antara golongan yang satu dengan yang lain. ${ }^{17}$

Pada dasarnya agama mengajarkan kedamaian, persaudaraan, kerukunan individu dan individu atau kelompok lain. Jadi agama itu tidak menghendaki

${ }^{15}$ Elizabeth K. Nottingham, Religion and Society, terj. Abdul Muis Naharong, (Rajawali, Jakarta, 1990), h.. 51-53.

${ }^{16}$ Abdurrahman Wahid, Muslim ditengah Pergumulan, (Leppanas, Jakarta, 1981), h. 5-7.

${ }^{17}$ Hendro Puspito, O.C.D., Sosiologi Agama, (Kanisius, yogyakarta, 1983), h. 127. 
perpecahan, permusuhan dan lain-lain. Namun dalam kenyataannya yang ada menunjukkan pengaruh agama terhadap masyarakat sering menimbulkan konflik. Para ahli sejarah atau filosofi sosial menyatakan, bahwa agama sering mempunyai efek yang negatif terhadap kesejahteraan manusia. Isu-isu keagamaan sering menjadikan timbulnya perang, keyakinan dalam suatu agama sering menimbulkan sikap manusia yang tidak toleran, loyalitas dalam agama hanya dapat menyatukan beberapa orang saja dan memisahkan dari kebanyakan orang lainnya. ${ }^{18}$

Pada pembahasan di atas telah dikemukakan bahwa agama mengajarkan persaudaraan, saling menolong, toleransi dan lain-lain. Fungsi ini sudah terbukti dari zaman dahulu hingga sekarang ini, namun disamping itu terdapat pula fakta yang negatif yaitu dengan agama terjadi suatu perpecahan, permusuhan antar sesama yang semuanya itu bersumber dari perbedaan dalam memahami dalil agama.

Bentuk bentuk konflik menurut sosiolog Hendro Puspito ${ }^{19}$ yang bersumber dari agama antara lain karena: Perbedaan doktrin dan sikap, perbedaan suku dan ras agama, perbedaan tingkat kebudayaan serta masalah mayoritas dan minoritas pemeluk agama. Konflik mempunyai hubungan erat dengan proses integrasi, semakin tinggi pertentangan, makin kecil derajat integrasi kelompok. Adapun faktor-faktor sosial yang menentukan terarahnya kehidupan sosial menuju integrasi adalah sebagai berikut:: Pertama, tujuan dari kelompok sosial. Kedua, sistem sosialnya, ketiga,sistem tindakannya dan yang keempat adalah sistem sangsi.

Untuk membahas peranan agama dalam mengatasi konflik sosial, baik disertai dengan contoh kasus yang relevan agar menjadi ilustrasi yang dapat mendeskripsikan peranan tersebut. Menurut Soerjono Soekanto,20 penyebab konflik sosial adalah perbedaan individu yang meliputi perbedaan pendirian dan perasaan, perbedaan latar belakang kebudayaan sehingga membentuk pribadi-pribadi yang berbeda, perbedaan kepentingan antara individu atau kelompok. $^{21}$ 1987, h. 32.

${ }^{18}$ Thomas F., Sosiologi Agama, (Rajawali Press, Jakarta. 1987), hal. 139.

${ }^{19}$ Hendro Puspito, Sosiologi Agama,.

${ }^{20}$ Soerjono Soekanto, Sosiologi Suatu Pengantar, Edisi Ketiga, (Jakarta : Rajawali Press),

\footnotetext{
${ }^{21}$ Ibid.,
} 
Kerusuhan yang terjadi pada tahun 1998 adalah contoh konflik yang cocok untuk menggambarkan pendapat Soekanto diatas. Peristiwa kerusuhan itu terjadi akibat konflik sosial yang telah menumpuk bertahun-tahun sebelumnya, kemudian terakumulasi dan pecah menjadi puncak konflik dengan rentetan peristiwa memilukan.

Agama adalah suatu dogma yang mengajarkan sekaligus mengajak kepada umat atau pengikutnya untuk mepercayai adanya Tuhan semesta alam. Tuhan mewahyukan kepada nabi dan rasul untuk menyampaikan perintah dan laranganNYA.

Ajaran agama bukan hanya berisi perintah dan larangan saja, tetapi juga pedoman, norma-norma, petunjuk hidup mana yang seharusnya dilakukan dan mana hal-hal yang sebaiknya ditinggalkan. Agama merupakan satu dari faktor pengendalian sosial. Orang yang yakin dan patuh pada ajaran agama, biasanya tata perilakunya akan terkendali dari bentuk perilaku menyimpang. Agama adalah motivator alami yang mendorong manusia agar selalu hidup baik dan teratur.

Selain sebagai faktor pengendali sosial, agama memiliki peran sosial sebagai faktor integratif bagi masyarakat, yang berarti peran agama dalam menciptakan suatu ikatan bersama, baik diantara anggota-anggota beberapa masyarakat maupun dalam kewajiban-kewajiban sosial yang membantu mempersatukan mereka. Hal ini dikarenakan nilai-nilai yang mendasari sistem-sistem kewajiban sosial didukung bersama oleh kelompok-kelompok keagamaan sehingga agama menjamin adanya konsensus dalam masyarakat.22 Dalam fungsinya yang integratif-sosial serta dalam konteks pembinaan kehidupan berbangsa dan bernegara berdasarkan Pancasila dan UUD 1945, agama mempunyai peranan sebagai faktor pemantapan stabilitas (keseimbangan). 23

\section{Solusi Konflik Sosial menurut Pandangan al-Quran}

Agama Islam adalah agama rahmat. Sebagaimana al-Qur'an menyatakan bahwa Nabi SAW. diutus sebagai rahmatan lil 'alamin.Untuk mengejawantahkan citacita besar yaitu rahmatan lil 'âlamîn diperlukan kerjasama antara umat manusia tidak terbatas antar intern umat Islam tetapi dengan non muslim pun perlu dijalin demi cita-cita di atas.

Untuk mewujudkan persaudaraan antarpemeluk agama, al-Quran telah memperkenalkan sebuah konsep yaitu ta'aruf. Seperti yang disebutkan dalam al-Quran. Allah berfirman dalam Q.S. al-Hujurat/49:13. 


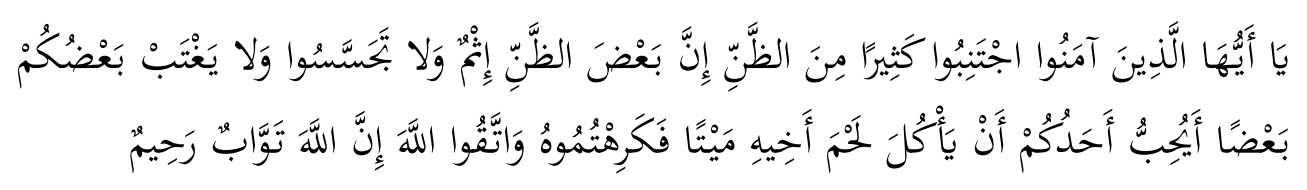

Terjemahnya: "Hai manusia, sesungguhnya Kami menjadikan kamu dari seorang laki-laki dan seorang wanita, dan menjadikan kamu berbangsa-bangsa dan bersuku-suku supaya saling mengenal. Sesungguhnya orang mulia di antara kamu di sisi Allah adalah orang yang paling bertakwa. Sesungguhnya Allah Maha Mengetahui lagi Maha Mengenal.”

Ayat di atas dijadikan sebagai dasar atas eksistensi interaksi sosial antar sesama manusia, dimana sebelumnya telah dijelaskan bahwa yang dimaksud dengan interaksi adalah aksi timbal balik dan kata ta'aruf dalam hadis tersebut juga bermakna saling karena dalam penggunaannya dipakai isim masdhar yang setimbang dengan kata tafa'ulun yang bermakna saling dimana fungsi isim adalah musyarakah. Selanjutnya kata ta'aruf dalam hadis tersebut dijelaskan bahwa yang dimaksud disitu adalah pentingnya untuk saling mengenal dan saling berinteraksi antar satu sama lain dalam hal umum, tetapi tidak dalam hal yang berhubungan dengan agama karena Allah telah membedakan diantara manusia yang dia cintai yaitu orang-orang yang beriman dan bertakwa kepadanya. Dengan kata lain, Allah telah memerintahkan hambanya untuk saling mengahargai dan saling menghormati dalam urusan-urusan sosial kemasyarakatan saja.

Ali M Hasan ${ }^{24}$ mengatakan bahwa dalam memahami fenomena konflik sosial keagamaan ada dua faktor pokok yang amat perlu mendapat perhatian, perbedaan faham agama sebagai sumber konflik dan kemerdekaan sebagai sumber integrasi.

Titik-temu antarpemeluk agama. Bahwa al-Quran menganjurkan agar dalam interaksi sosial, bila tidak ditemukan persamaan hendaknya masingmasing mengakui keberadaan pihak lain, dan tidak perlu saling menyalahkan. Seperti yang disebutkan dalam Q.S. An-Nisa/4: 44s:

\footnotetext{
${ }^{22}$ Agam Fatih Herlambang dll, Fungsi dan Peran Iislam Dalam Kehidupan,Makalah Agama pada Akademi Keperawatan Pemerintah Provinsi Jawa Tengah,2012 / 2013.

${ }^{23}$ M. Dahlan Al Barry, dalam Dalam Arianti Youli Blog. "Peran dan Fungsi Agama dalam Masyarakat,"http://ariantiyoulie.blogspot.com/2013/11/peran-dan-fungsi-agama-dalammasyarakat.html, diunduh pada 14-05-2016

${ }^{24}$ Ali M. Hasan, Bagaimana Sikap Muslim Menghadapi Khilafiyah, (Bulan Bintang, Jakarta, 1975), h.. 13-38.
} 


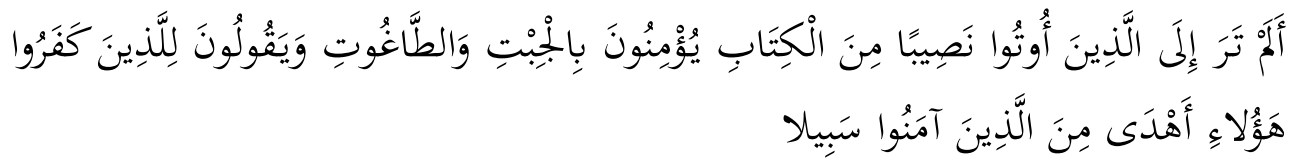

Terjemahnya: Apakah kamu tidak memperhatikan orang-orang yang diberi bahagian dari Al Kitab? Mereka percaya kepada jibt dan thaghut, dan mengatakan kepada orang-orang kafir (musyrik Mekah), bahwa mereka itu lebih benar jalannya dari orang-orang yang beriman

Bahkan al-Quran mengajarkan kepada Nabi Muhammad SAW. dan umatnya untuk menyampaikan kepada penganut agama lain, setelah "kalimah sawa' (titik-temu)" tidak dicapai. Seperti yang disebutkan dalam al-Quran. Allah berfirman:

Artinya : Katakanlah: "Siapakan yang memberi rezeki kepadamu dari langit dan dari bumi?" Katakanlah: "Allah", dan Sesungguhnya Kami atau kamu (orang-orang musyrik), pasti berada dalam kebenaran atau dalam kesesatan yang nyata. Katakanlah: "Kamu tidak akan ditanya (bertanggung jawab) tentang dosa yang Kami perbuat dan Kami tidak akan ditanya (pula) tentang apa yang kamu perbuat". Katakanlah: "Tuhan kita akan mengumpulkan kita semua, kemudian Dia memberi keputusan antara kita dengan benar. dan Dia-lah Maha pemberi keputusan lagi Maha Mengetahui".

Jalinan persaudaraan antara seorang Muslim dan non-Muslim sama sekali tidak dilarang oleh Islam, selama pihak lain menghormati hak-hak umat Islam. Seperti yang disebutkan dalam Q.S.Al-Maidah/5: 42.

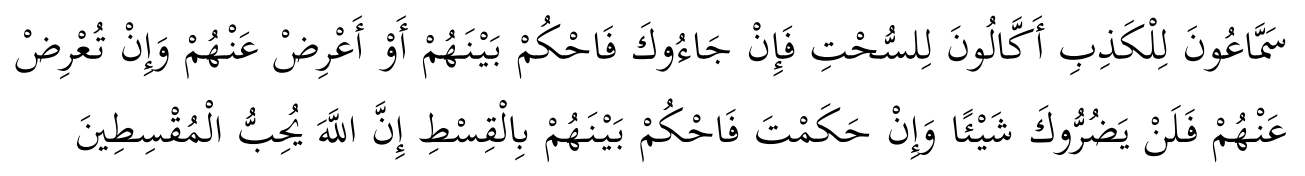

Terjemahnya: Mereka itu adalah orang-orang yang suka mendengar berita bohong, banyak memakan yang haram. Jika mereka (orang Yahudi) datang kepadamu (untuk meminta putusan), maka putuskanlah (perkara itu) di antara mereka, atau berpalinglah dari mereka; jika kamu berpaling dari mereka maka mereka tidak akan memberi mudarat kepadamu sedikit pun. Dan jika kamu memutuskan perkara mereka, maka putuskanlah (perkara itu) di antara mereka dengan adil, sesungguhnya Allah menyukai orang-orang yang adil.

Ketika sebagian sahabat Nabi memutuskan bantuan keuangan/material kepada sebagian penganut agama lain dengan alasan bahwa mereka bukan 
Muslim, al-Quran menegur mereka dengan seperti yang disebutkan berfirman Allah dalam Q.S. At-Taubah/9 : 33

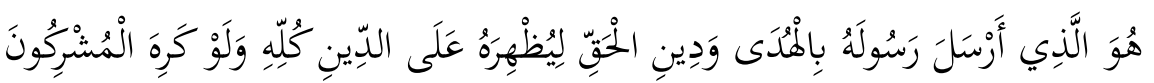

Terjemahnya: Dialah yang telah mengutus Rasul-Nya (dengan membawa) petunjuk (Al Qur'an) dan agama yang benar untuk dimenangkan-Nya atas segala agama, walaupun orang-orang musyrik tidak menyukai.

Sejarah telah mencatat bagaimana interaksi sosial dan muamalah dengan orang-orang non muslim yang dilakukan oleh Rasulullah dan para sahabatnya. Rasulullah SAW. sendiri pernah menerima hadiah dari raja/kepala suku kafir. Bahkan Rasul pun pernah memberi hadiah kepada mereka.

Dalam urusan muamalah, Rasulullah SAW. selalu berbuat ihsan. Sejarah membuktikan bagaimana sikap ihsan yang dilakukan oleh Rasullah SAW. terhadap musuh-musuh utamanya ketika beliau berhasil menaklukkan Makkah.

Rasulullah SAW. pun pernah bertransaksi dengan seorang yahudi. Sebagaimana riwayat berikut ini :

Dari Aisyah r.a. (ia berkata): "Sesungguhnya Nabi saw. telah membeli makanan dari seorang Yahudi buat dibayar disatu waktu, dengan menggadaikan (memberikan jaminan) baju besi kepadanya.

Untuk keperluan makanan keluarganya, suatu hari Rasulullah SAW. meminjam tiga puluh sha' gandum kepada seorang Yahudi dari suku Aus yang bernama Abu Syahmi. Dalam satu riwayat si Yahudi tersebut menagih utang gandum tersebut kepada Rasul dan Rasulullah SAW. memberikan baju besinya sebagai jaminan bagi utangnya. Dalam riwayat lain baju besi Nabi tersebut masih tergadai sampai beliau meninggal dan akhirnya Abu Bakar menebusnya dan diberikan kepada Ali bin Abi Thalib.

Berdasarkan riwayat ini, barangkali kita bertanya-tanya mengapa Rasulullah SAW. tidak meminjam bahkan meminta kepada para sahabatnya? Atas pertanyaan ini Imam Nawawi memberikan beberapa alternatif jawaban yaitu: Rasulullah SAW. berbuat demikian sebagai bayan (penjelasan) atas bolehnya bermuamalah dengan Yahudi. Tidak ada makanan yang baik yang dibutuhkan oleh keluarganya kecuali ada pada si Yahudi itu. Para sahabat tidak akan berani mengambil jaminan dan menghargakannya. Oleh sebab itu, Rasul bertransaksi dengan Yahudi supaya tidak menyulitkan para sahabatnya. 
Dengan jawaban di atas, menurut penulis, apapun yang dilakukan oleh Rasul pada dasarnya mengandung ta'lim dan tasyri. Ada poin-poin pelajaran dan pensyariatan yang ingin disampaikan oleh Rasulullah SAW yaitu tolong menolong tidak hanya dapat dilakukan dengan sesama muslim tetapi dengan non muslim pun bisa dilakukan tetapi tentunya memiliki batasan-batasan syari'at/agama.

Imam Bukhari menempatkan hadis di atas di dalam pokok bahasan jual beli, jaminan (rungguh/borgh), salam (pesanan), dan utang piutang, begitu juga imam-imam ahli hadis ternama mayoritas mereka menempatkan teks hadis di atas pada pokok bahasan muamalah. Menurut Abdul Kadir Hasan, dalam urusan mu'amalah agama Islam tidak memberi batasan-batasan tertentu, hanya agama melarang dalam kejadian-kejadian yang tetap, yang dapat menimbulkan hal-hal yang tidak baik, seperti menipu, memberatkan orang, memaksa dan menyusahkan orang. Dalam muamalah berlaku hadis "Antum a'lamu biumuri dunyakum”.

Menurut Imam Nawawi dalam hadis di atas terdapat hukum diperbolehkannya muamalah dengan ahli dzimmah dan hukum tetapnya kepemilikan mereka terhadap harta benda mereka.

Imam as Syaukany berpendapat bahwa hadis di atas merupakan dalil/ petunjuk atas: Pertama, disyariatkannya jaminan dalam utang piutang baik di waktu perjalanan ataupun di tempat sendiri. Kedua, dengan jelas hadis ini membolehkan kita kerjasama dengan non muslim sepanjang barang yang dipakai muamalah itu tidak haram.

Jadi, yang dimaksudkan dengan interasksi sosial menurut al-Quran adalah sikap saling mengahargai dan saling menghormati dalam urusan-urusan sosial kemasyarakatan atau dalam bidang muamalah.

Dalam sekup yang lebih besar setelah hijrah ke Madinah, Nabi Muhammad mengatur hubungan dengan berbagai lapisan masyarakat Madinah, dan merekamnya dalam suatu dokumentasi yang dicatat dalam sumber-sumber sejarah. Tujuan dokumentasi ini adalah untuk menjelaskan komitmen masingmasing kelompok di Madinah dengan memberikan batasan hak-hak dan kewajiban. Dalam sumber-sumber lama, dokumen ini disebut al-kitab dan ash shahifah. Penelitian modern menyebutkan ad-Dustur 'konstitusi' atau al Watsiqah 'dokumen'.

Dalam kitab Majmu'atul watsaiqis Siyâsah dokumen itu memuat 47 klausul. Klausul 24 hingga 57 membicarakan perjanjian damai dengan Yahudi. 
Klausul 25-35 membicarakan hubungan antara orang-orang Yahudi dari Aus dan Khazraj. Klausul ini menjelaskan asal usul suku Arab mereka, dan membenarkan aliansi mereka dengan kalangan muslim : "Yahudi Bani Aus adalah satu komunitas dengan orang-orang yang beriman.” Klausul 45, perjanjian melebar untuk meliputi sekutu-sekutu muslim dan Yahudi yang lain.

Apabila diteliti dokumen itu dibangun atas dasar kerjasama untuk menegakkan keadilan, kesalehan, perdamaian, dan pertahanan bersama. Selanjutnya jika berbicara tentang konteks ke-Indonesiaan bahwa tujuan pokok semua negara pada dasarnya bermuara pada terwujudnya negara aman, tentram, subur makmur,. Yang dalam bahasa al-Qur'an adalah baldatun Thayyibatun wa rabbun ghabur.

Tujuan di atas seharusnya merupakan agenda bersama bagi semua kalangan agama, suku, etnis, maupun kelompok. Yang menjadi landasan terwujudnya cita-cita besar itu diperlukan suatu pedoman etika. Pedoman etika perlu digunakan menurut dan sesuai dengan konteks macam kegiatan dan organisasi.

Menurut Magnis Suseno, secara garis besarnya, etika dapat dilihat sebagai pedoman yang berisikan aturan-aturan baku yang mengatur tindakan-tindakan pelaku dalam sebuah profesi, yang dalam pedoman tersebut terserap prinsipprinsip moral dan nilai-nilai yang mendukung dan menjamin dilakukannya kegiatan profesi si pelaku sebagaimana seharusnya, sesuai dengan hak dan kewajibannya. Sehingga, peranannya dalam sesuatu struktur kegiatan adalah fungsional dalam memproses masukan menjadi keluaran yang bermutu.

Dalam konteks ke-Indonesiaan, Masdar Hilmy berpandangan bahwa bagi bangsa Indonesia, adanya keragaman budaya merupakan kenyataan sosial yang sudah niscaya. Meski demikian, hal itu tidak secara otomatis diiringi dengan penerimaan yang positif pula. Bahkan, banyak fakta yang justru menunjukkan fenomena yang sebaliknya: keragaman budaya telah memberi sumbangan terbesar bagi munculnya ketegangan dan konflik. Sehingga, tak pelak modal sosial (social capital) itu justru menjadi kontraproduktif bagi penciptaan tatanan kehidupan berbangsa yang damai, harmoni dan toleran. Untuk itu, diperlukan upaya untuk menumbuhkembangkan kesadaran multikulturalisme agar potensi positif yang terkandung dalam keragaman tersebut dapat teraktualisasi secara benar dan tepat.

Dalam hubungannya dengan dasar-dasar kerjasama dalam Islam, sebagaimana telah disebut pada bahasan sebelumnya, dengan maksud agar Islam 
menjadi rahmatan lil alamin, tidak hanya dirasakan mereka yang menganut Islam -dalam wilayah Republik Indonesia - perlu objektivikasi nilai Islam. Menurut Kuntowijoyo, yang dimaksud dengan objektivasi nilai Islam adalah elaborasi nilai-nilai internal Islam ke dalam kategori objektif. Kata objektivikasi berpasangan dengan 'eksternalisasi'. Yang dimaksud dengan eksternalisasi adalah kegiatan-kegiatan konkritisasi dari nilai-nilai yang dihayati oleh seorang muslim secara internal.

Eksternalisasi nilai-nilai keadilan yang berdimensi multikultural, misalnya, merupakan suatu agenda besar yang perlu senantiasa dijalankan oleh semua komponen bangsa. Isu keadilan tidak hanya untuk kaum minoritas tetapi bagi mayoritas pun perlu ditegakkan. Bahkan bagi penganut faham multikultural seharusnya isu mayoritas-minoritas sudah tidak dipermasalahkan lagi karena sudah meruju ke Pedoman etika menurut dan sesuai dengan konteks macam kegiatan dan organisasi.

Didalam al-Qur,an Allah Swt berfirman :

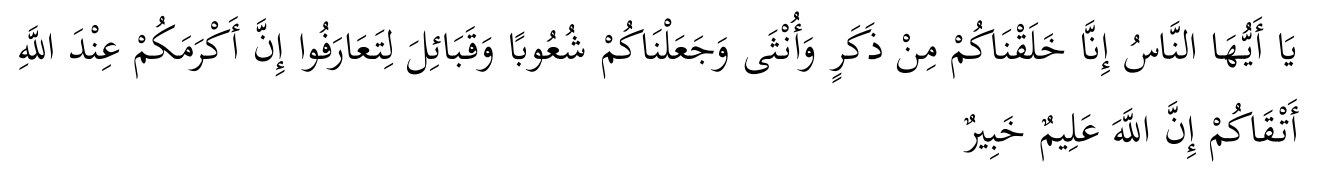

Terjemahnya: "Hai manusia, sesungguhnya Kami menjadikan kamu dari seorang laki-laki dan seorang wanita, dan menjadikan kamu berbangsa-bangsa dan bersukusuku supaya saling mengenal. Sesungguhnya orang mulia di antara kamu di sisi Allah adalah orang yang paling bertakwa. Sesungguhnya Allah Maha Mengetahui Lagi Maha Mengenal."

Ajaran Islam tentang pentingnya saling kenal mengenal yaitu upaya seorang manusia untuk saling menghormati dan saling menghargai telah lama di kumandangkannya dengan sempurna dan indah. Namun, kebanyakan dari manusia tidak menyadari apa arti sesungguhnya dari konsep ta'aruf itu sendiri, sehingga dapat terhenti dan menyimpang dari aturan-aturan yang telah digariskan oleh al-Quran.

Sebagaimana syair yang mengatakan, "mawaddatuhu tadûmu likulli haulin, wa hal kullun mawaddatuhu tadûmu", kasih sayangnya (manusia) selalu kekal untuk segala hal yang menakutkan, dan apakah setiap orang itu kasih sayangnya selalu kekal. Hal ini karena tidak diniatkan semata karena Allah yang tidak dijadikan sebagai ladang amal bahkan hanya untuk memperoleh keuntungan dan kesenangan duniawi saja. 
Konsep ta'âruf yang terkandung dalamnya makna kasih sayang tidaklah berujung, sedangkan rasa kasih sayang adalah sebuah fitrah yang mesti direalisasikan terhadap sesama manusia sepanjang kehidupan di dunia ini ada, tentunya dalam koridor-koridor Islam. Ini berarti bahwa Islam tidak mengenal waktu, jarak, dan tempat akan sebuah kasih sayang baik terhadap teman, sahabat, kerabat, dan keluarganya sendiri. Rasulullah SAW bersabda ;artinya : Barang siapa tidak menyayangi sesamanya, Allah tidak akan menyayanginya.

Dalam hadis tersebut dijelaskan betapa pentingnya untuk saling mengasihi dan menyayangi sebagai bentuk penegasan bahwa manusia adalah makhluk social yang sepantasnya saling berinteraksi. Juga dalam hadis tersebut dipahami bahwa kasih sayang seorang Muslim tidaklah terhadap saudara seMuslim saja, tapi untuk semua umat manusia. Rasulullah SAW. bersabda, "Sekalikali tidaklah kalian beriman sebelum kalian mengasihi." Wahai Rasulullah, "Semua kami pengasih," jawab mereka. Berkata Rasulullah, "Kasih sayang itu tidak terbatas pada kasih sayang salah seorang di antara kalian kepada sahabatnya (mukmin), tetapi bersifat umum (untuk seluruh umat manusia)."

Jelaslah bahwa konsep interaksi social yang ada dalam al-Quran itu sangat junjung tinggi. Apalagi jika mencoba untuk lebih mendalami kehidupan rasulullah, maka interaksi sosial itu sangat dianjurkan oleh Nabi tentunya dalam koridor-koridor Islam. Dan pada akhirnya, para sahabat Nabi pun benar-benar merealisasikan makna interkasi sosial sebagai bentuk kasih sayang antar sesama manusia, tentunya dengan tujuan untuk mencapai keridaan Allah semata. Maka memang pantas bahwa konsep al-Quran yang mewakili agama Islam dikatakan sebagai agama rahmatan lil 'âlamiin.

\section{Kesimpulan}

Sepanjang sejarah kemanusiaan, konflik-konflik sosial selalu ada dalam komunitas masyarakat, meskipun bentuk dan model konflik tersebut bermacam-macam dan skalanyapun bertingkat-tingkat dari satu daerah dengan daerah lain.

Konflik sosail sesungguhnya dapat dicegah, apabila keinginan, kepentingan, dan keadilan di tengah-tengah masyarakat terpenuhi dengan baik, sehingga memberikan rasa aman, damai, dan penuh persaudaraan yang harmonis.

Agama Islam dengan segala ajaran yang dibawah oleh Nabi Muhammad SAW, secara signifikan mampu menyelesaikan berbagai konflik-konflik yang 
terjadi selama ini. Sebab hanya dengan pendekatan agama (Islam) berbagai masalah yang sering terjadi di sekitar masyarakat yang majemuk dapat di redam, dan di cegah. Agama dapat dijadikan sebuah solusi komprehensif untuk sebuah masyarakat bangsa dan negara, sebagai landasan teologi dalam berinteraksi satu golongan masyarakat dengan golongan lainnya.

Untuk itu al-Quran menawarkan spirit dalam menginspirasi dan memotivasi untuk mewujudkan resolusi konflik menuju perdamaian. Pertama, melakukan al-tabayun (klarifikasi). Dalam hal ini al-tabayun dijadikan sebagai upaya mencari kejelasan dan klarifikasi atas sebuah informasi, terlebih informasi yang masih simpang-siur kejelasannya, yang dapat menimbulkan fitnah dan konflik. Spirit al-tabayun dikatakan dalam al-Quran untuk menguji kebenaran informasi dari seorang fasiq (Q.S. al-Hujurat: 6).Kedua, melakukan tahkim (upaya mediasi). Dalam hal ini upaya tahkim dilakukan sebagai salah satu cara mendamaikan dua belah pihak yang tengah berkonflik dengan mendatangkan mediator sebagai juru damai, sebagaimana dikatakan dalam Q.S. al-Nisa': 35. Sebagai catatan bahwa seorang mediator harus 'berdiri di tengah'. Artinya, tanpa memihak dan bersimpati kepada salah satu pihak yang tengah berkonflik. Ia seharusnya mendorong dan mengondisikan kedua pihak tersebut ke arah perdamaian. Ketiga, melakukan al-syura (musyawarah). Upaya ini ditempuh guna memecahkan persoalan (baca: mencari solusi) dengan mengambil keputusan bersama. Hal ini dianggap penting dalam kasus terjadinya konflik. Pentingnya musyawarah ditegaskan dalam Q.S. Ali Imran: 158.Keempat, sikap al-afwu (saling memafkan). Ketika terjadi konflik, maka masing-masing pihak cenderung mempertahankan ego sektoral mereka. Sehingga al'afwu merupakan indikator awal lahirnya kebaikan dan ketakwaan seseorang (Q.S. al-Baqarah: 237), yang mampu menciptakan kondisi perdamaian dalam kehidupan manusia.Kelima, tekad al-ishlah (berdamai). Setelah upaya saling memaafkan, maka tekad untuk berdamai pun menjadi sebuah keharusan. Sebab al-Quran sendiri menegaskan untuk berdamai dalam berteologi/berkeyakinan (Q.S. al-Baqarah: 208). Bahkan ayat ini ditafsirkan sebagai ayat perdamaian. Sebagaimana penafsiran Ibnu 'Asyur dalam karyanya, al-Tahrir wa al-Tanwir. Ia menafsirkan kata al-silmi dalam ayat tersebut dengan pengertian al-sulh (perdamaian), dan tark al-harb (meninggalkan peperangan).Keenam, sikap al-'adl (berlaku adil). Keadilan (al-'adalah) merupakan suatu keniscayaan dalam menciptakan kondisi damai dan harmoni. Sebab kezaliman (lawan dari keadilan) pada dasarnya akan menyulut konflik bagi pihak yang dizalimi. Term yang digunakan dalam al-Quran untuk menyebut keadilan sangatlah beragam, seperti al'adl, al-qisth, dan al-mizan. Keadilan merupakan 
indikator ketakwaan seseorang (Q.S. al-Maidah: 8), sementara ketakwaan akan mengantarkan kepada keberkahan, kesejahteraan dan kedamaian (Q.S. al-A'raf: 96).Ketujuh, adanya al-hurriyah (jaminan kebebasan). Al-Quran sangat menjunjung tinggi kebebasan, termasuk kebebasan dalam menentukan keyakinan atau agama (al-Baqarah: 256). Bahkan Allah memberikan kebebasan apakah seseorang itu mau beriman atau kafir (al-Kahfi: 19). Oleh karena kebebasan merupakan hak setiap manusia yang diberikan oleh Tuhan, tidak ada pencabutan hak atas kebebasan kecuali di bawah dan setelah melalui proses hukum yang tepat dan benar.

\section{Daftar Pustaka}

Ahmadi, Abu, Pengantar Sosiologi, Ramadhan, Solo, 1975.

Berger, Peter L., The Sacred Canapy, terj. Hartono, LP3ES, Jakarta, 1991.

Coser , Lewis, The Function of Social Conflict. New York: Free Press, 1956

Elizabeth, Nottingham, K., Agama dan Masyarakat, Suatu Pengantar Sosiologi Agama, terj. Abd. Muis Narahong, Rajawali, Jakarta, 1990.

F., Thomas., Sosiologi Agama, Rajawali Press, Jakarta. 1987.

Johnson, Doyle Paul Johnson, Sociological Theory Classical fonders and Contemporary Perspectives, jili I, terj. Robert. M.Z. Lawang, Jakarta: Gramedia, 1988.

Nottingham, Elizabeth K., Religion and Society, terj. Abdul Muis Naharong, Rajawali, Jakarta, 1990.

Puspito, Hendro, O.C.D., Sosiologi Agama, Kanisius, yogyakarta, 1983.

Soekanto, Soerjono, Sosiologi Suatu Pengantar, (Jakarta: Rajawali Pers), 2007.

Soeprapto, Riyadi, InteraksionismeSimbolik, PerspektifSosiologi Modern, (Jakarta:

PT. PustakaPelajardanAveroes Press Malang, 2002

Sofyan, Abu, Pluralisme Keberagaman di Pemukiman Baru, Studi Tentang Konflik dan Integrasi Antara Warga Nahdlotul 'Ulama dengan Muhammadiyah di Perumahan Taman Jenggala Sidoarjo, Umm, Malang, 2001.

Sopiah,Perilaku Organisasi. Yogyakarta : Penerbit Andi. 2000.

Susanto, Astrid, Pengantar Sosiologi dan Perubahan Sosial, Putra A. Bardin, Semarang, 1999.

Veeger, K.J., Realitas Sosial, Refleksi Filsafat Sosial Atas Hubungan Individu Masyarakat Dalam Cakrawala Sejarah sosiologi, Jakarta: PT. Gramedia Pustaka Utama, 1985.

Wahid, Abdurrahman, Muslim ditengah Pergumulan, Leppanas, Jakarta, 1981. 